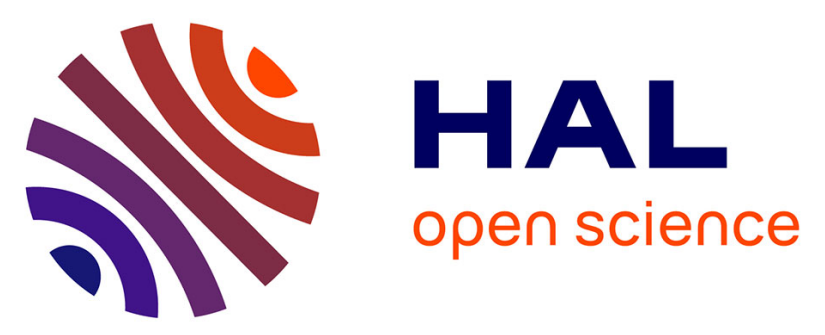

\title{
DNA relatedness among strains of Streptomyces pathogenic to potato in France: description of three new species, S. europaeiscabiei sp. nov. and S. stelliscabiei sp. nov. associated with common scab, and S. reticuliscabiei sp. nov. associated with netted scab
}

Karima Bouchek-Mechiche, L. Gardan, P. Normand, B. Jouan

\section{To cite this version:}

Karima Bouchek-Mechiche, L. Gardan, P. Normand, B. Jouan. DNA relatedness among strains of Streptomyces pathogenic to potato in France: description of three new species, S. europaeiscabiei sp. nov. and S. stelliscabiei sp. nov. associated with common scab, and S. reticuliscabiei sp. nov. associated with netted scab. International Journal of Systematic and Evolutionary Microbiology, 2000, 50 (1), pp.91-99. 10.1099/00207713-50-1-91 . hal-01600668

\section{HAL Id: hal-01600668 \\ https://hal.science/hal-01600668}

Submitted on 1 Jun 2020

HAL is a multi-disciplinary open access archive for the deposit and dissemination of scientific research documents, whether they are published or not. The documents may come from teaching and research institutions in France or abroad, or from public or private research centers.
L'archive ouverte pluridisciplinaire HAL, est destinée au dépôt et à la diffusion de documents scientifiques de niveau recherche, publiés ou non, émanant des établissements d'enseignement et de recherche français ou étrangers, des laboratoires publics ou privés.

\section{다(1)(2)}

Distributed under a Creative Commons Attribution - ShareAlikel 4.0 International 


\section{DNA relatedness among strains of Streptomyces pathogenic to potato in France: description of three new species, S. europaeiscabiei sp. nov. and S. stelliscabiei sp. nov. associated with common scab, and S. reticuliscabiei sp. nov. associated with netted scab}

\author{
K. Bouchek-Mechiche, ${ }^{1}$ L. Gardan, ${ }^{2}$ P. Normand ${ }^{3}$ and B. Jouan ${ }^{1}$
}

1 INRA, Station de Pathologie Végétale, BP 29 35650 Le Rheu, France

2 INRA, Station de Pathologie Végétale et Phytobacteriologie, 49071 Cedex Beaucouzé, France

3 UMR 5557 CNRS, Ecologie Microbienne, 69622 Villeurbanne Cedex, France
Author for correspondence: K. Bouchek-Mechiche. Tel: +332992828 10. Fax: +332992851 80 . e-mail: bouchek@rennes.inra.fr

The genomic relatedness was evaluated by DNA-DNA hybridization for 23 strains ( 21 were pathogenic and two were saprophytic strains) isolated from lesions of common and netted scab in France and 19 strains from other countries, including type strains of Streptomyces species. Three genomospecies were defined within the conventional species of Streptomyces scabies, and these genomospecies were different from other pathogenic described species (Streptomyces acidiscabies, Streptomyces caviscabies) based on previously published phenotypic data. Two of these genomospecies ( 1 and 3) correspond to new species, for which the names Streptomyces europaeiscabiei sp. nov. (with type strain CFBP $4497^{\top}$ ) and Streptomyces stelliscabiei sp. nov. (with type strain CFBP $4521^{\top}$ ) are proposed.

Genomospecies 2 corresponds to $S$. scabies (with type strain CFBP $4517^{\top}=$ ATCC $\left.49173^{\top}\right)$, and includes only one French strain. The pathogenic strains associated with netted scab lesions constituted a new species that was named Streptomyces reticuliscabiei sp. nov. (with type strain CFBP 4531'). The G+C content of DNA from the three strains CFBP $4497^{\top}$ (S. europaeiscabiei), CFBP $4521^{\top}$ (S. stelliscabiei), CFBP $4531^{\top}$ (S. reticuliscabiei) was $71.3,71.0$ and $69.8 \mathrm{~mol} \%$, respectively. Phylogenetic analysis based on 16S rRNA gene sequences showed that the type strain CFBP $4497^{\top}$ was very similar to the type strain of S. scabies, whereas, the type strain of S. stelliscabiei, CFBP $4521^{\top}$, was very similar to the type strain of Streptomyces bottropensis. On the basis of $16 S$ rRNA gene sequences, the type strain of S. reticuliscabiei, CFBP $4531^{\top}$, differed extensively from the other strains of Streptomyces tested.

Keywords: scab, Streptomyces scabies, potato, DNA-DNA hybridization, 16S rRNA sequences

\section{INTRODUCTION}

Common, netted and russet scabs are diseases of

Abbreviations: ISP, International Streptomyces Project; OMPG, 1-omethyl- $x$-galactopyranoside.

The EMBL accession numbers for the almost full-length double-stranded $16 \mathrm{~S}$ rRNA gene sequences are AJ007423 for CFBP $4497^{\top}$, AJ007428 for CFBP $4531^{\top}$ and AJ007429 for CFBP $4521^{\top}$. potato caused by several species of Streptomyces. Common scab is prevalent in all potato growing areas of the world. It causes deep- or shallow-pitted lesions on potato tubers and on a number of root crops including carrot, radish, beet and turnip. Netted scab of potato has only been reported in European countries, and causes superficial, brown lesions on the skin of the tubers and on the roots (Labruyère, 1971; Bång, 1979; Scholte \& Labruyère, 1985). Russet scab 
has been reported in North America (Harrison, 1962; Faucher et al., 1993) and Japan (Oniki et al., 1986). The symptoms of russet scab on the tuber surface, are very similar to those of netted scab. However, there are two main differences between the two diseases, in the species of Streptomyces involved and the optimal conditions for disease development. Common, netted and russet scabs are complex bacterial diseases, because of the diversity of their symptoms and causal agents.

Streptomyces scabies is by far, the most important bacterial species causing common scab. Lambert \& Loria (1989a) clarified the taxonomic position of Streptomyces scabies, and redefined the species as having grey, smooth spores borne in spiral chains, and as utilizing the nine diagnostic sugars listed in the International Streptomyces Project (ISP) (Shirling \& Gottlieb, 1966), and producing melanin. S. scabies strains form a relatively homogeneous group on the basis of the limited number of phenotypic features studied (Lambert \& Loria, 1989a; Faucher et al., 1992). However, molecular studies involving techniques such as DNA-DNA hybridization have shown a great diversity within the strains identified as $S$. scabies (Healy \& Lambert, 1991; Paradis et al., 1994). Other species, including Streptomyces acidiscabies (Bonde \& McIntyre, 1968; Lambert \& Loria, 1989b), Streptomyces caviscabies (Faucher et al., 1995; Goyer et al., 1996), and other as yet unnamed species of Streptomyces (Doering-Saad et al., 1992), also cause common scab. The taxonomic position of strains causing netted scab has not yet been determined. The russet scab strains reported in Canada (Faucher et al., 1993) are related to Streptomyces aureofaciens. However, other species of Streptomyces, currently unclassified, were also isolated from lesions of russet scab in the United States (Harrison, 1962) and Japan (Oniki et al., 1986).

In France, common and netted scabs cause large economic losses, and identification of the causal agents is needed especially to elaborate efficient strategies to control these diseases. A phenotypic study (BouchekMechiche et al., 1998) has shown differences between strains identified as $S$. scabies, resulting in the definition of three phenotypic groups. These groups may correspond to three species of which two are new. Another phenotypic group of strains, different from both $S$. scabies and $S$. acidiscabies, has been associated with symptoms of netted scab.

The aims of this work were (i) to confirm by DNADNA hybridization that the new phenotypic groups correspond to new genomic species, (ii) to determine, on the basis of complete $16 \mathrm{~S}$ rRNA gene sequences, the phylogenetic relationships between the defined species and other species of Streptomyces for which 16S rRNA gene sequences have been deposited in sequence databases. According to our results three new species are described: Streptomyces europaeiscabiei sp. nov., Streptomyces stelliscabiei sp. nov. and Streptomyces reticuliscabiei sp. nov.

\section{METHODS}

Bacterial strains. Forty-two strains were used in this study, 23 of which were isolated in France (21 were pathogenic and two were saprophytic strains) and 19 in other countries (Table 1). All strains were originally isolated from scab symptoms on potato or other root crops. These strains have been phenotypically described and cluster into six phena with some unclustered strains, as indicated in Table 1 (Bouchek-Mechiche et al., 1998). All strains were routinely cultured on yeast extract-malt extract agar (Pridham et al., 1956-1957), and were stored at $-20^{\circ} \mathrm{C}$ in tryptone-yeast extract broth (Pridham \& Gottlieb, 1948) containing $20 \%$ (v/v) glycerol.

DNA extraction and purification. All strains were grown in YEME medium (Chater et al., 1982) for $48 \mathrm{~h}$ at $25^{\circ} \mathrm{C}$ with shaking. The cultures were harvested by centrifugation at $3000 \mathrm{~g}$ for $10 \mathrm{~min}$, and the mycelial pellets were rinsed and suspended in $10 \mathrm{ml}$ cold TS $(50 \mathrm{mM}$ Tris, $15 \%$ sucrose, $\mathrm{w} / \mathrm{v} ; \mathrm{pH} 8.0$ ). The tubes containing the suspensions were placed in boiling water for $3 \mathrm{~min}$ and in liquid nitrogen for $3 \mathrm{~min}$. This operation was repeated three times to weaken the cell walls. Lysozyme $\left(5 \mathrm{mg} \mathrm{m}^{-1}\right)$ and EDTA $(0 \cdot 1 \mathrm{M})$ were added and the mixture incubated at $37^{\circ} \mathrm{C}$ for $1 \mathrm{~h}$. Proteinase $\mathrm{K}\left(0.2 \mathrm{mg} \mathrm{ml}^{-1}\right)$ was added and the incubation continued for $15 \mathrm{~min}$. SDS was added to a concentration of $2 \%(\mathrm{w} / \mathrm{v})$ and the homogenate was incubated at $37^{\circ} \mathrm{C}$ overnight, until full lysis was achieved. DNA was purified as described elsewhere (Brenner et al., 1982).

DNA-DNA hybridization. Native DNA was labelled in vitro by nick translation with tritium-labelled nucleotides (Amersham International). The S1 nuclease-trichloroacetic acid method was used for hybridization (Crosa et al., 1973; Grimont et al., 1980). The reassociation temperature was $75^{\circ} \mathrm{C}$. DNA-DNA hybridization was achieved using labelled DNAs from CFBP $4497^{\mathrm{T}}$ (subphenon 1a), S. scabies CFBP $4517^{\mathrm{T}}$ (subphenon 1b), CFBP $4521^{\mathrm{T}}$ (subphenon 1c), CFBP $4531^{\mathrm{T}}$ (phenon 2, netted scab strain) and S. acidiscabies CFBP $4539^{\mathrm{T}}$ (phenon 4).

DNA base composition. The $\mathrm{G}+\mathrm{C}$ contents of CFBP $4497^{\mathrm{T}}$, CFBP $4521^{\mathrm{T}}$ and CFBP $4531^{\mathrm{T}}$, were determined by thermal denaturation (Marmur \& Doty, 1962) according to the following equation: $\mathrm{G}+\mathrm{C}$ content $=2.44\left(T_{\mathrm{m}}-53.9\right)$ (Mandel \& Marmur, 1968), where $T_{\mathrm{m}}$ is the melting temperature. S. scabies CFBP $4517^{\mathrm{T}}$ and $S$. acidiscabies CFBP $4539^{\mathrm{T}}$ were used as standards.

Analysis of the $16 \mathrm{~S}$ rRNA gene. Double-stranded amplification of the whole rrs gene was carried out by a modification of the PCR procedure of Mullis \& Faloona (1987). The two following universal primers previously described by Normand et al. (1996) were used to amplify the 16S RNA gene: FGPS5-281 (5'-ATGGARAGYTTGATCCTGGCTCA-3', where R stands for $\mathrm{G}$ or A and $\mathrm{Y}$ for $\mathrm{C}$ or T) and FGPS1509'-153 (5'-AAGGAGGGGATCCAGCCGCA-3'). PCR was carried out in a final volume of $50 \mu \mathrm{l}$ containing template DNA, reaction buffer $(10 \mathrm{mM}$ Tris/ $\mathrm{HCl}, \mathrm{pH} 8.3,1.5 \mathrm{mM} \mathrm{MgCl}, 50 \mu \mathrm{M} \mathrm{KCl}, 10 \%$, w/v, gelatin), $200 \mu \mathrm{M}$ each dNTP, $0.5 \mu \mathrm{M}$ oligomers and $2 \mathrm{U}$ TaqI DNA polymerase (Gibco-BRL). Thirty-five cycles of amplification were carried out: denaturation of DNA at $94{ }^{\circ} \mathrm{C}$ for $1 \mathrm{~min}$, annealing at $60{ }^{\circ} \mathrm{C}$ for $1 \mathrm{~min}$ and extension at $72^{\circ} \mathrm{C}$ for $2 \mathrm{~min}$. The amplification products were analysed by subjecting $5 \mu \mathrm{l}$ of the reaction mixture to electrophoresis in a $2 \%(w / v)$ (Metaphor; FMC) agarose gel. A $1500 \mathrm{bp}$ double-stranded DNA fragment was amplified. 
Table 1. Origins of strains of Streptomyces spp. isolated from various hosts used in this study

\begin{tabular}{|c|c|c|}
\hline Taxon & $\begin{array}{l}\text { Phenotypic } \\
\text { group* }\end{array}$ & Host and geographical origin \\
\hline \multicolumn{3}{|l|}{ S. scabies (common scab) } \\
\hline $\begin{array}{l}\text { CFBP 4496, CFBP } 4497^{\mathrm{T}} \text {, CFBP } 4498, \text { CFBP } 4499, \text { CFBP } 4501, \text { CFBP } \\
\text { 4502, CFBP 4506, CFBP 4507, CFBP 4508, CFBP 4509, CFBP } 4510\end{array}$ & la & Solanum tuberosum, France \\
\hline CFBP 4513 (= IPO 1595), CFBP 4511 (= IPO 1626) & la & Solanum tuberosum, The Netherlands \\
\hline CFBP 4495 & la & Daucus carota, France \\
\hline CFBP 4503 (= PD 1030), CFBP $4512(=$ PD 1027) & la & Daucus carota, The Netherlands \\
\hline CFBP $4504(=956 \mathrm{C})$ & la & Solanum tuberosum, Russia \\
\hline CFBP 4505 (= PD 259) & 1a & Beta vulgaris, The Netherlands \\
\hline CFBP $4517^{\mathrm{T}}\left(=\operatorname{ATCC} 49173^{\mathrm{T}}\right)$ & $1 b$ & Solanum tuberosum, USA \\
\hline CFBP $4516(=$ DNK 043) & $1 b$ & Solanum tuberosum, South Africa \\
\hline CFBP 4518 & $1 b$ & Solanum tuberosum, France \\
\hline CFBP $4520(=$ EF 35) & $1 b$ & Solanum tuberosum, Canada \\
\hline CFBP $4521^{\mathrm{T}}$, CFBP 4522, CFBP 4523 & lc & Solanum tuberosum, France \\
\hline CFBP $4524(=$ Scab 4017) & Unclustered & Solanum tuberosum, Japan \\
\hline CFBP 4526 (= DNK 057), CFBP 4528 (= DNK 058) & Unclustered & Solanum tuberosum, South Africa \\
\hline \multicolumn{3}{|l|}{ Streptomyces spp. (netted scab) } \\
\hline CFBP 4530, CFBP 4531 ${ }^{\mathrm{T}}$, CFBP 4532, CFBP 4533, CFBP 4534 & 2 & Solanum tuberosum, France \\
\hline \multicolumn{3}{|l|}{ S. acidiscabies (common scab) } \\
\hline CFBP $4537(=9025)$, CFBP $4539^{\mathrm{T}}\left(=\right.$ ATCC $\left.49003^{\mathrm{T}}\right)$ & 4 & Solanum tuberosum, USA \\
\hline CFBP $4538(=$ Scab 43$)$ & 4 & Solanum tuberosum, Japan \\
\hline \multicolumn{3}{|l|}{ S. aureofaciens (russet scab) } \\
\hline CFBP $4550(=\mathrm{EF} 69)$ & 6 & Solanum tuberosum, Canada \\
\hline CFBP $4551^{\mathrm{T}}\left(=\operatorname{ATCC} 10762^{\mathrm{T}}\right)$ & 6 & Soil, unknown \\
\hline \multicolumn{3}{|l|}{ S. griseus } \\
\hline CFBP $4546^{\mathrm{T}}\left(=\right.$ ATCC $\left.23345^{\mathrm{T}}\right)$ & Unclustered & Soil, unknown \\
\hline S. caviscabies & Unclustered & Solanum tuberosum, Canada \\
\hline \multicolumn{3}{|l|}{ Streptomyces spp. (saprophytic strains) } \\
\hline CFBP 4529 & Unclustered & Solanum tuberosum, France \\
\hline CFBP 4543 & 5 & Solanum tuberosum, France \\
\hline
\end{tabular}

CFBP, Collection Française de Bacteries Phytopathogènes, INRA, Angers, France; ATCC, American Type Culture Collection, Manassas, VA, USA. The numbers in parentheses are the original designation of foreign strains.

* See Bouchek-Mechiche et al. (1998).

DNA sequencing. DNA was sequenced with an automatic ABI sequencer (Applied Biosystems) by Société ESGS (Evry, France) using four internal primers (FGPS485-292, CAGCAGCCGCGGTAA; FGPS1047-295, ATGTTGGGTTAAGTC; FGPS505'-313, GTATTACCGCGGCTGCTG; FGPS910'-270, AGCCTTGCGGCCGTACTCCC), and the amplification primers (Normand et al., 1996). Almost full-length double-stranded $16 \mathrm{~S}$ rRNA gene sequences were obtained for all strains tested and have been deposited in the EMBL database, with the following accession numbers: AJ007423 for CFBP $4497^{\mathrm{T}}$, AJ007428 for CFBP $4531^{\mathrm{T}}$ and AJ007429 for CFBP $4521^{\mathrm{T}}$. GenBank was scanned for related sequences using the BLAST algorithm (Altschul et al., 1997) and the related sequences of representative Streptomyces spp. were included in subsequent analyses. Sequences were aligned using CLUSTAL x (Thompson et al., 1997) and indel-containing regions were excluded from the analyses. Matrix pairwise comparisons of nucleic acid sequences were corrected for multiple base substitutions by the two-parameter method of Kimura (1980). Phylogenetic trees were constructed by the neighbour-joining (Saitou \& Nei, 1987), parsimony (Kluge \& Farris, 1969) and maximum-likelihood (Felsenstein, 1981) methods. A bootstrap confidence analysis was performed for 1000 replicates to determine the reliability of the distance tree topologies obtained (Felsenstein, 1985). The resulting trees were graphically represented using NJPLOT and PHYLO_WIN software (Perrière \& Gouy, 1996).

\section{RESULTS}

\section{DNA relatedness}

The DNA-DNA hybridization results are shown in Table 2. Thirty-three of the 42 strains tested fell into five discrete DNA relatedness groups (genomospecies). Of the nine other strains, five have not yet been classified, of which three were unclustered (CFBP 4524, CFBP 4526, CFBP 4528) and two were sap- 
K. Bouchek-Mechiche and others

Table 2. Levels of DNA relatedness between strains of species of Streptomyces

\begin{tabular}{|c|c|c|c|c|c|}
\hline \multirow[t]{2}{*}{ Source of unlabelled DNA from: ${ }^{*}$} & \multicolumn{5}{|c|}{ Relative binding $(\%)$ at $75^{\circ} \mathrm{C}$ with labelled DNA from: } \\
\hline & CFBP $4497^{\mathrm{T}}$ & CFBP $4517^{\mathrm{T}}$ & CFBP $4521^{\mathrm{T}}$ & CFBP $4531^{\mathrm{T}}$ & CFBP $4539^{\mathrm{T}}$ \\
\hline \multicolumn{6}{|l|}{ S. scabies (phenon 1) } \\
\hline \multicolumn{6}{|l|}{ Genomospecies 1 (subphenon 1a) } \\
\hline $\begin{array}{l}\text { CFBP } 4495(\mathrm{~F}) \\
\text { CFBP } 4496(\mathrm{~F})\end{array}$ & 90 & NT & 44 & NT & NT \\
\hline CFBP 4496 (F) & 88 & NT & NT & NT & NT \\
\hline CFBP $4497^{\mathrm{T}}(\mathrm{F})$ & 100 & 52 & 47 & 19 & 13 \\
\hline CFBP $4498(\mathrm{~F})$ & 88 & 42 & 51 & NT & NT \\
\hline CFBP 4499 (F) & 70 & 50 & 35 & NT & NT \\
\hline CFBP $4501(\mathrm{~F})$ & 85 & 47 & 43 & NT & NT \\
\hline CFBP $4502(\mathrm{~F})$ & 87 & 50 & NT & 20 & NT \\
\hline CFBP 4503 & 77 & 25 & 54 & NT & NT \\
\hline CFBP 4504 & 81 & NT & NT & NT & NT \\
\hline CFBP 4505 & 70 & NT & NT & NT & NT \\
\hline CFBP 4506 (F) & 75 & 38 & 46 & NT & NT \\
\hline CFBP 4507 (F) & 72 & NT & NT & NT & NT \\
\hline CFBP 4508 (F) & 89 & 42 & NT & NT & NT \\
\hline CFBP 4509 (F) & 88 & 46 & NT & NT & NT \\
\hline CFBP $4510(\mathrm{~F})$ & 96 & 42 & 41 & 25 & NT \\
\hline CFBP 4512 & 71 & 37 & NT & NT & NT \\
\hline CFBP 4513 & 82 & 49 & NT & 21 & NT \\
\hline CFBP 4511 & 78 & NT & NT & NT & NT \\
\hline Mean \pm SD & $82 \cdot 9(9 \cdot 0)$ & & & & \\
\hline \multicolumn{6}{|l|}{$\begin{array}{l}\text { Mean } \pm \text { SD } \\
\text { Genomospecies } 2 \text { (subphenon 1b) }\end{array}$} \\
\hline CFBP 4516 & 45 & 95 & 37 & NT & 21 \\
\hline CFBP $4517^{\mathrm{T}}\left(=\right.$ ATCC $\left.49173^{\mathrm{T}}\right)$ & 42 & 100 & 40 & 20 & NT \\
\hline CFBP $4518(\mathrm{~F})$ & 41 & 72 & 51 & NT & NT \\
\hline CFBP 4520 & 42 & 90 & 39 & NT & NT \\
\hline Mean \pm SD & & $89(10 \cdot 5)$ & & & \\
\hline \multicolumn{6}{|l|}{$\begin{array}{l}\text { Mean } \pm \text { SD } \\
\text { Genomospecies } 3 \text { (subphenon 1c) }\end{array}$} \\
\hline CFBP $4521^{\mathrm{T}}(\mathrm{F})$ & 41 & 52 & 100 & 24 & 17 \\
\hline CFBP $4522(\mathrm{~F})$ & 55 & 56 & 85 & NT & NT \\
\hline CFBP 4523 (F) & 40 & 47 & 95 & NT & NT \\
\hline \multirow{2}{*}{\multicolumn{4}{|c|}{$\begin{array}{l}\text { Mean } \pm \text { SD } \\
\text { Not yet classified (unclustered) }\end{array}$}} & & \\
\hline & & 52 & 36 & NT & NT \\
\hline CFBP 4524 & 41 & 45 & NT & NT & NT \\
\hline CFBP 4526 & 42 & 48 & 40 & NT & NT \\
\hline CFBP 4528 & & & & & \\
\hline \multicolumn{6}{|l|}{ Netted scab strains (phenon 2) } \\
\hline \multicolumn{6}{|l|}{ Genomospecies 4} \\
\hline CFBP $4530(\mathrm{~F})$ & 19 & 21 & NT & 76 & NT \\
\hline CFBP $4531^{\mathrm{T}}(\mathrm{F})$ & 20 & 19 & 18 & 100 & 14 \\
\hline CFBP $4532(\mathrm{~F})$ & NT & 25 & 18 & 82 & NT \\
\hline CFBP 4533 (F) & NT & NT & NT & 72 & NT \\
\hline CFBP 4534 (F) & NT & NT & NT & 73 & NT \\
\hline Mean \pm SD & & & & $81 \cdot 7(13)$ & \\
\hline \multicolumn{6}{|l|}{ S. acidiscabies (phenon 4) } \\
\hline \multicolumn{6}{|l|}{ Genomospecies 5} \\
\hline CFBP 4537 & NT & NT & NT & NT & 85 \\
\hline CFBP 4538 & NT & 13 & NT & 14 & 74 \\
\hline CFBP $4539^{\mathrm{T}}\left(=\operatorname{ATCC} 49003^{\mathrm{T}}\right)$ & 15 & 19 & 17 & 16 & 100 \\
\hline Mean \pm SD & & & & & $86 \cdot 3(13)$ \\
\hline
\end{tabular}


Scab-associated Streptomyces spp. isolated in France

Table 2 (cont.)

\begin{tabular}{|c|c|c|c|c|c|}
\hline \multirow[t]{2}{*}{ Source of unlabelled DNA from: ${ }^{*}$} & \multicolumn{5}{|c|}{ Relative binding $(\%)$ at $75^{\circ} \mathrm{C}$ with labelled DNA from: } \\
\hline & CFBP $4497^{\mathrm{T}}$ & CFBP $4517^{\mathrm{T}}$ & CFBP $4521^{\mathrm{T}}$ & CFBP $4531^{\mathrm{T}}$ & CFBP $4539^{\mathrm{T}}$ \\
\hline S. aureofaciens (phenon 6) & & & & & \\
\hline $\begin{array}{l}\text { CFBP } 4550 \\
\text { CFBP } 4551^{\mathrm{T}}\left(\text { ATCC } 10762^{\mathrm{T}}\right)\end{array}$ & $\begin{array}{l}6 \\
5\end{array}$ & $\begin{array}{r}11 \\
9\end{array}$ & $\begin{array}{r}\text { NT } \\
4\end{array}$ & $\begin{array}{l}9 \\
7\end{array}$ & $\begin{array}{l}\text { NT } \\
\text { NT }\end{array}$ \\
\hline S. caviscabies & & & & & \\
\hline CFBP $4545^{\mathrm{T}}$ (unclustered) & 13 & 17 & 16 & 14 & NT \\
\hline $\begin{array}{l}\text { S. griseus } \\
\qquad \text { CFBP } 4546^{\mathrm{T}}\end{array}$ & 10 & 13 & 10 & 14 & NT \\
\hline $\begin{array}{l}\text { Saprophytic strains } \\
\text { CFBP } 4529 \text { (F) (unclustered) } \\
\text { CFBP } 4543 \text { (F) (subphenon 5) }\end{array}$ & $\begin{array}{l}18 \\
25\end{array}$ & $\begin{array}{l}26 \\
26\end{array}$ & $\begin{array}{l}\text { NT } \\
\text { NT }\end{array}$ & $\begin{array}{l}24 \\
21\end{array}$ & $\begin{array}{l}17 \\
19\end{array}$ \\
\hline
\end{tabular}

$\mathrm{NT}$, Strains not tested.

* $(\mathrm{F})$, isolated in France.

rophytic (CFBP 4529, CFBP 4543), and the remaining four strains corresponded to Streptomyces aureofaciens (2), S. caviscabies (1) and Streptomyces griseus (1).

Relatedness within genomospecies was 70-100\% homology. Relatedness between the five genomospecies and all other strains tested ranged from 4 to $56 \%$ (Table 2).

Genomospecies 1 contained 18 pathogenic strains (subphenon 1a) that were $70-100 \%($ mean $=82.9 \%$; $\mathrm{SD}=9$ ) related to pathogenic strain CFBP $4497^{\mathrm{T}}$ and corresponded to a discrete DNA hybridization group. Twelve of the 18 pathogenic strains were isolated in France, five in the Netherlands and one in Russia, from common scab lesions, mostly on potato, but also on carrot and beet.

Genomospecies 2 contained four pathogenic strains (subphenon $1 b)$ that were $72-100 \%($ mean $=89 ; \mathrm{SD}=$ $10.5)$ related to type strain of $S$. scabies and thus belonged to this species. These strains were isolated from common scab lesions on potato. Only one French strain belonged to genomospecies 2 , which also contained strains isolated from other countries: one strain was isolated in Canada, one in South Africa and the type strain, S. scabies CFBP $4517^{\mathrm{T}}$, was isolated in the USA.

Genomospecies 3 contained three pathogenic strains (subphenon 1c) that were $85-100 \%($ mean $=93 \cdot 3 ; \mathrm{SD}$ $=7 \cdot 6$ ) related to pathogenic strain CFBP 4521 and corresponded to a discrete DNA hybridization group. These strains were isolated from star-like lesions on potato in a single region of France.

The three unclustered pathogenic strains, which had the same primary characteristics as $S$. scabies were less than $52 \%$ related to labelled DNAs from CFBP $4497^{\mathrm{T}}$ (genomospecies 1), CFBP $4517^{\mathrm{T}}$ (genomospecies 2) and CFBP $4521^{\mathrm{T}}$ (genomospecies 3 ).
Genomospecies 4 contained five pathogenic strains (phenotypic group 2) that were $72-100 \%$ (mean $=$ $81.5 ; \mathrm{SD}=13$ ) related to $\mathrm{CFBP} 4531^{\mathrm{T}}$ and corresponded to a discrete DNA hybridization group. These strains were isolated from netted scab lesions on potato in France.

Genomospecies 5 contained three pathogenic strains of $S$. acidiscabies that were $74-100 \%$ (mean $=86 \cdot 3$; $\mathrm{SD}=13$ ) related to their type strain, CFBP $4539^{\mathrm{T}}$.

\section{DNA base composition}

Strain CFBP $4497^{\mathrm{T}}$ (genomospecies 1) contained $71.3 \mathrm{~mol} \% \mathrm{G}+\mathrm{C}, \mathrm{CFBP} 452 \mathrm{1}^{\mathrm{T}}$ (genomospecies 3 ) had $71.7 \mathrm{~mol} \% \mathrm{G}+\mathrm{C}$ and CFBP $4531^{\mathrm{T}}$ (genomospecies 4 ) had $69.8 \mathrm{~mol} \% \mathrm{G}+\mathrm{C}$. We obtained $\mathrm{G}+\mathrm{C}$ content of $70.3 \mathrm{~mol} \%$ for the reference strains, S. scabies CFBP $4517^{\mathrm{T}}$ and $S$. acidiscabies CFBP $4539^{\mathrm{T}}$, which was consistent with the values of $70.5 \mathrm{~mol} \%$ (CFBP $4517^{\mathrm{T}}$ ) and $71 \cdot 1 \mathrm{~mol} \%\left(\mathrm{CFBP} 4539^{\mathrm{T}}\right.$ ) determined previously (Healy \& Lambert, 1991).

\section{Amplification from chromosomal DNA}

Chromosomal DNA isolated from pure cultures of Streptomyces isolates was used as a template for amplification. The DNA amplified was, in each case, a single product of the expected length (approx. $1500 \mathrm{bp}$ ), corresponding to the region between primers FGPS5-281 and FGPS1509'-153.

\section{Sequence comparison and phylogenetic analysis of the amplified 16S rRNA gene}

An almost complete rrs (16S rRNA gene) sequence was obtained for all isolates studied. Sequences were compared with those in GenBank and were found to be most similar to those of Streptomyces spp. The sequences obtained start at coordinates 20 of the 


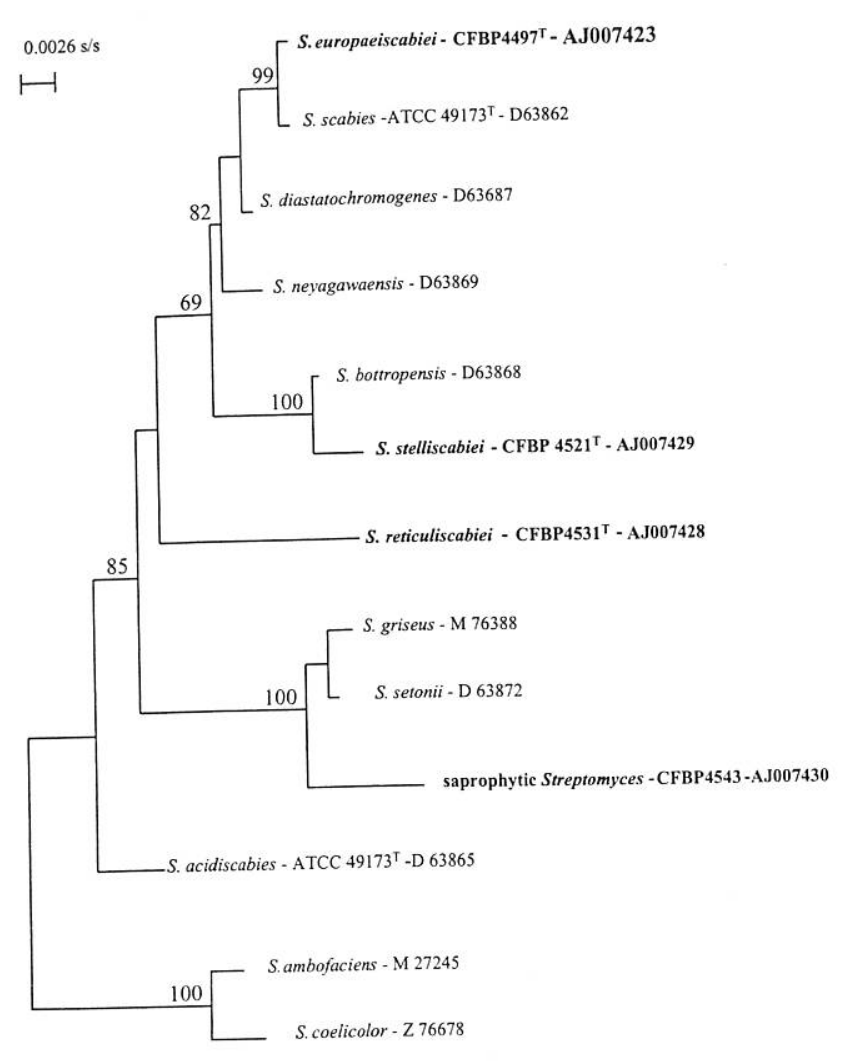

Fig. 1. Phylogenetic tree of Streptomyces spp. based on the $16 \mathrm{~S}$ rRNA gene sequences obtained by the neighbour-joining method (Saitou \& Nei, 1987) using a bootstrap approach (Felsenstein, 1985) to determine the reliability of the topology obtained (numbers given above the nodes). The EMBL accession numbers are given after the strain names. The bar indicates a distance of 0.0026 substitutions per site.

S. griseus sequence (EMBL no. M76388) and end at coordinates 1513. Sequences were aligned with published rrs sequences from Streptomyces spp., and four regions containing indels were identified at positions 57-67, 154-180, 973-977 and 1413-1420. These regions were not included in subsequent analysis.

The levels of similarity among the Streptomyces species examined in this study were more than $95.9 \%$. The common scab isolate of genomospecies 1, CFBP $4497^{\mathrm{T}}$ was most similar to S. scabies strains (ATCC $49173^{\mathrm{T}}$ ) with sequence identities of $99 \cdot 8 \%$. Phylogenetic analysis confirmed the distance findings and grouped CFBP $4497^{\mathrm{T}}$ in a tight cluster with $S$. scabies ATCC $49173^{\mathrm{T}}$ sequences, supported by $99 \%$ of bootstrap replicates (Fig. 1). The nearest neighbour to the common scab strain, CFBP $4521^{\mathrm{T}}$, which belongs to genomospecies 3 , was Streptomyces bottropensis with $99.6 \%$ sequence identity. Clustering of CFBP $4521^{\mathrm{T}}$ with $S$. bottropensis was supported by $100 \%$ of bootstrap replicates and by parsimony (Fig. 1). The level of similarity between the netted scab strain CFBP $4531^{\mathrm{T}}$, which belong to genomospecies 4 and the other pathogenic strains of
Streptomyces tested was relatively low. The nearest neighbour to the saprophytic strain CFBP 4543 was Streptomyces setonii with $99 \cdot 2 \%$ sequence identity, supported by $100 \%$ of bootstrap replicates and by parsimony.

\section{DISCUSSION *}

In a previous study (Bouchek-Mechiche et al., 1998), we showed that all pathogenic strains isolated in France from lesions of common scab on potatoes and other root vegetables were identified as S. scabies based on the following primary characteristics used to describe this species: grey spores borne in spiral chains, utilization of the nine ISP sugars (Shirling \& Gottlieb, 1966), melanine production and sensitivity to streptomycin. We also demonstrated that $S$. scabies strains are phenotypically heterogeneous, and can be divided into three groups (subphena $1 \mathrm{a}, 1 \mathrm{~b}$ and $1 \mathrm{c}$ ) and unclustered strains, which were differentiated by the following biochemical test: assimilation of 1-o-methyl$\alpha$-galactopyranoside (OMPG), trans-aconitate, 5keto-D-gluconate, betain, $\mathrm{D}(+)$ trehalose and gentisate. Another phenotypic group (phenon 2) of pathogenic strains was associated with netted scab lesions.

All French strains were tested for pathogenicity on Solanum tuberosum cultivars Urgenta (known to be susceptible to common scab) and Bintje (known to be susceptible to both netted or common scabs), seedlings of carrot (Daucus carota cv. Premia) or seedlings of radish (Raphanus sativus cv. Polka) in a greenhouse at $20{ }^{\circ} \mathrm{C}$ (Bouchek-Mechiche et al., unpublished).

In this study the DNA relatedness of 23 strains isolated from potato scab lesions in France was assessed and compared with that of 19 strains isolated in other countries, including the type strains of validly described species of Streptomyces. DNA-DNA hybridization showed that 21 pathogenic strains of the 23 French strains were grouped into four genomospecies strictly correlated with the phenotypic clusters, while the two saprophytic strains did not fall into these groups.

The 16 pathogenic $S$. scabies strains isolated from common scab lesions in France were phenotypically heterogeneous and formed three genomospecies. Genomospecies 1 and genomospecies 3 were found to constitute new discrete DNA relatedness groups and genomospecies 2 was identified as $S$. scabies because it included the type strain, CFBP $4517^{\mathrm{T}}$. Previous studies have shown that the strains identified as $S$. scabies constitute a heterogeneous DNA relatedness group. In fact, Healy \& Lambert (1991) showed that the level of DNA relatedness between two strains with the primary characteristics of S. scabies could be as low as $20 \%$. Similarly, Paradis et al. (1994) found that S. scabies includes two diverse genomic groups of strains based on DNA-DNA hybridization, and that these groups also differed in fatty acid and protein profiles. These two studies thus implied that the $S$. scabies species was 
too large, and give support to the idea of revising the taxonomic status of these strains.

All strains of genomospecies 1 were distantly related to type strains of S. scabies CFBP $4517^{\mathrm{T}}(25-52 \%)$ and are distinguished phenotypically by the utilization of trans-aconitate, $\mathrm{D}(+)$ trehalose, OMPG and did not use betain. However, phylogenetic analyses based on 16S rRNA gene sequences showed that CFBP $4497^{\mathrm{T}}$ strain belonging to genomospecies 1 was closely related to the type strain of S. scabies, CFBP $4517^{\mathrm{T}}$. This conflict between low DNA-DNA hybridization values and high 16S rRNA similarity levels was met by Fox et al. (1992) working on Bacillus species. Thus, according to Stackebrandt \& Goebel (1994), the resolution power of DNA hybridization is significantly higher than the resolution power of sequence analysis of $16 \mathrm{~S}$ rRNA gene, consequently DNA hybridization remains the optimal method to measure the level of relatedness between highly related organisms.

Strains isolated from hosts other than potato (carrot and beet) were also assigned to genomospecies 1 on the basis of DNA-DNA hybridization. This is consistent with the work of Goyer \& Beaulieu (1997), who observed that Streptomyces spp. isolated from carrot lesions belong to one of the two genomic clusters of $S$. scabies.

All strains of genomospecies 3 were also distantly related to type strains of S. scabies CFBP $4517^{\mathrm{T}}$ $(47-56 \%)$ and are distinguished phenotypically by the utilization of trans-aconitate, $\mathrm{D}(+)$ trehalose and did not use 5-keto-D-gluconate or betain. The strains of genomospecies 3 were also distantly related to the type strain CFBP $4497^{\mathrm{T}}$ of genomospecies 1 , and can be distinguished phenotypically by the non-utilization of OMPG, 5-keto-D-gluconate or gentisate. However, phylogenetic analysis based on 16S rRNA gene sequences showed that strain CFBP $4521^{\mathrm{T}}$ of genomospecies 3 was closely related to $S$. bottropensis. Healy \& Lambert (1991) also found that some strains of Streptomyces sp. phenotypically similar to $S$. scabies and not very similar to type strain CFBP $4517^{\mathrm{T}}$ on the basis of DNA-DNA hybridization, are very similar to the $S$. bottropensis type strain.

Our phylogenetic analysis, based on 16S rRNA gene sequences, gave results similar to those of Takeuchi et al. (1996), who found that all strains with the primary characteristics of $S$. scabies had 16S rRNA gene sequences similar to those of Streptomyces diastatochromogenes, $S$. bottropensis and Streptomyces neyagawaensis, but less similar to those of other species of Streptomyces.

All netted scab strains of genomospecies 4 were distantly related $(<25 \%$ relatedness) to strains of other scab pathogens: genomospecies 1, genomospecies 2 (S. scabies), genomospecies 3, S. acidiscabies, $S$. caviscabies, Streptomyces aureofaciens. On the basis of phenotypic features (Bouchek-Mechiche et al., 1998), strains of netted scab formed a homogeneous group readily differentiated by various characteristics (pigmentation, morphology and carbon sources utilization) from other described pathogenic species of Streptomyces. These strains were pathogenic only on some susceptible cultivars of potato (data not shown), on which they produced typical symptoms of netted scab on the surface of tubers and on the roots. The $16 \mathrm{~S}$ rRNA gene sequences, of the strain of genomospecies 4 were not very similar to those of the other strains tested, indicating the lack of a close relationship to other scab pathogens.

The two species, S. acidiscabies and S. caviscabies were not detected in the regions that were prospected in France. Nevertheless, they may be present, but at a lower frequency than the pathogenic strains of genomospecies 1, 2, 3 and 4 (netted scab strains).

In accordance with the definition of bacterial species of Wayne et al. (1987), from our phenotypic and genomic data for the strains isolated from common scab lesions in France, two new species were delineated within the conventional species of $S$. scabies. We suggest the name Streptomyces europaeiscabiei for the strains of genomospecies 1 which are European in origin and Streptomyces stelliscabiei for the strains of genomospecies 3, isolated in France from star-like lesions on potato. We also identified a new species associated with netted scab lesions in France, for which we propose the name Streptomyces reticuliscabiei.

\section{Description of Streptomyces europaeiscabiei sp. nov.}

Streptomyces europaeiscabiei (eu.ro.pa.ei.sca'bi.ei. L. adj. europaeus european; L. n. scabies mange; M.L. n. europaeiscabiei referring to the European origin of the strains).

Spores are grey and are borne in mature spiral chains. Melanin is produced on tyrosine agar. All ISP sugars are used: L-arabinose, D-fructose, D-glucose, Dmannitol, inositol, raffinose, rhamnose, sucrose, Dxylose. Degradation of xanthine differed between the strains studied. All strains are susceptible to $20 \mu \mathrm{g}$ streptomycin $\mathrm{ml}^{-1}$ and $0.5 \mu \mathrm{g}$ crystal violet $\mathrm{ml}^{-1}$. They are not susceptible to $25 \mu \mathrm{g}$ oleandomycin $\mathrm{ml}^{-1}$ or 10 IU penicillin $\mathrm{G} \mathrm{ml} \mathrm{m}^{-1}$. They utilize trans-aconitate, $\mathrm{D}(+)$ trehalose, OMPG, melibiose, 5-keto-D-gluconate and most (about $78 \%$ ) of the strains assimilate gentisate. They do not use betain, mucate, Dsaccharate, DL-lactate and turanose. The $\mathrm{G}+\mathrm{C}$ content of the type strain is $71.3 \mathrm{~mol} \%$. These strains were isolated from common scab lesions, mostly on potato, but also on carrot and beet and have been confirmed to be pathogenic on potato cvs Bintje and Urgenta, on carrot cv. Premia and on radish cv. Polka. The type strain has been deposited in the French Collection of Phytopathogenic Bacteria (Collection Française des Bacteries Phytopathogènes) as CFBP $4497^{\mathrm{T}}$, the International Collection of Microorganism from Plants as ICMP $13714^{\mathrm{T}}$, and the National Collection of Plant Pathogenic Bacteria as NCPPB $4039^{\mathrm{T}}$. This strain was isolated from common scab lesions on potato in 
France. It has the physiological and biochemical characteristics of the species.

\section{Description of Streptomyces stelliscabiei sp. nov.}

Streptomyces stelliscabiei (stel.li.sca'bi.ei. L. n. stellatus star; L. n. scabies mange; M.L. n. stelliscabiei referring to lesions from which these strains were isolated, which look like stars).

Spores are grey and are borne in mature spiral chains. Melanin is produced on tyrosine agar. All ISP sugars are used: L-arabinose, D-fructose, D-glucose Dmannitol, inositol, raffinose, rhamnose, sucrose, Dxylose. Most strains studied degrade xanthine. All strains are susceptible to $20 \mu \mathrm{g}$ streptomycin $\mathrm{ml}^{-1}$, $0.5 \mu \mathrm{g}$ crystal violet $\mathrm{ml}^{-1}, 100 \mu \mathrm{g}$ oleandomycin $\mathrm{ml}^{-1}$ and $5 \%(\mathrm{w} / \mathrm{v}) \mathrm{NaCl}$. They are not susceptible to $25 \mu \mathrm{g}$ oleandomycin $\mathrm{ml}^{-1}$ or $10 \mathrm{IU}$ penicillin $\mathrm{G} \mathrm{ml}^{-1}$. They utilize trans-aconitate, $\mathrm{D}(+)$ trehalose, $\alpha$ $\mathrm{D}(+)$ melibiose but do not assimilate 5-keto-Dgluconate, OMPG, betain, mucate, D-saccharate, DLlactate, gentisate or turanose. The $\mathrm{G}+\mathrm{C}$ content of the type strain is $71.7 \mathrm{~mol} \%$. These strains were isolated from star-like common scab lesions on potato cv. Belle de Fontenay and have been confirmed to be pathogenic on potato cvs Bintje and Urgenta, on carrot cv. Premia and on radish cv. Polka. The type strain is CFBP $4521^{\mathrm{T}}$ $\left(=\operatorname{ICMP} 13715^{\mathrm{T}}=\mathrm{NCPPB} 4040^{\mathrm{T}}\right)$. This strain was isolated from star-like common scab lesions on potato tubers cv. Belle de Fontenay in France. This strain has the physiological and biochemical characteristics of the species.

\section{Description of Streptomyces reticuliscabiei sp. nov.}

Streptomyces reticuliscabiei (re.ti.cu.li.sca'bi.ei. L. n. reticulum reticulum; L. n. scabies mange; M.L. n. reticuliscabiei referring to the reticulum aspect of the symptoms of the disease).

Spores are light grey, and are borne in mature flexuous chains. Melanin is not produced on tyrosine agar. They do not grow in the presence of $0.5 \mu \mathrm{g}$ crystal violet $\mathrm{ml}^{-1}, 20 \mu \mathrm{g}$ streptomycin $\mathrm{ml}^{-1}, 100 \mu \mathrm{g}$ oleandomycin $\mathrm{ml}^{-1}$ or $5 \%(\mathrm{w} / \mathrm{v}) \mathrm{NaCl}$. They are not susceptible to $10 \mathrm{IU}$ penicillin $\mathrm{G} \mathrm{ml}^{-1}$ and some (about $60 \%$ ) of the strains are not susceptible to $25 \mu \mathrm{g}$ oleandomycin $\mathrm{ml}^{-1}$. All ISP sugars (fructose, D-glucose D-mannitol, inositol, raffinose, rhamnose, sucrose, D-xylose) are used as carbon sources. These strains utilize $\alpha$-D $(+)$ melibiose, mucate, D-saccharate, $\mathrm{D}(+)$ trehalose, 5-keto-D-gluconate. They do not assimilate trans-aconitate or OMPG. Most (about $80 \%$ ) of the strains utilize DL-lactate and turanose. Some strains use betain. The $\mathrm{G}+\mathrm{C}$ content of the type strain is $69.8 \mathrm{~mol} \%$. These strains were isolated from netted scab lesions on potato $\mathrm{cv}$. Bintje and have been confirmed to be pathogenic only on potato cv. Bintje. The type strain is CFBP $4531^{\mathrm{T}}\left(=\mathrm{ICMP} 13716^{\mathrm{T}}=\right.$ NCPPB $4041^{\mathrm{T}}$ ). It was isolated from lesions of netted scab on potato tubers in France.

\section{ACKNOWLEDGEMENTS}

We would like to thank J. Marechal (Université Lyon I, France) and S. Belouin (INRA Angers, France) for technical assistance, C. Pasco (INRA Rennes, France), C. Beaulieu (Université Sherbrooke, Québec, Canada), A. de Klerk (Agricultural Research Council, Pretoria, South Africa), R. Loria (Cornell University Ithaca, NY, USA), K. Scholte (Wageningen University, the Netherlands) and C. Bizet (Institut Pasteur, Paris, France) for kindly providing strains. This work received support from GNIS, ONIFLHOR and CNIPT.

\section{REFERENCES}

Altschul, S. F., Madden, T. L., Schäffer, A. A., Zhang, J., Zhang, Z., Miller, W. \& Lipman, D. J. (1997). Gapped BLAST and PSI-BLAST: a new generation of protein database search programs. Nucleic Acids Res 25, 3389-3402.

Bång, H. (1979). Studies on potato russet scab. I. A characterization of different isolates from northern Sweden. Acta Agric Scand 29, 145-150.

Bonde, M. R. \& McIntyre, G. A. (1968). Isolation and biology of a Streptomyces sp. causing potato scab in soils below pH 5.0. Am Potato J 45, 273-278.

Bouchek-Mechiche, K., Guérin, C., Jouan, B. \& Gardan, L. (1998). Streptomyces species isolated from potato scabs in France: numerical analysis of 'Biotype 100' carbon sources assimilation data. Res Microbiol 149, 653-663.

Brenner, D. J., McWorter, A.C., Leete Knutson, J. K. \& Steigerwalt, A. G. (1982). Escherichia vulneris: a new species of Enterobacteriaceae associated with human wounds. J Clin Microbiol 15, 1133-1140.

Chater, K. F., Hopwood, D. A., Kieser, T. \& Thompson, C. J. (1982). Gene cloning in Streptomyces. Curr Top Microbiol Immunol 96, 69-95.

Crosa, J. M., Brenner, D. J. \& Falkow, S. (1973). Use of singlestrand-specific nuclease for analysis of bacterial and plasmid deoxyribonucleic acid homo- and heteroduplexes. J Bacteriol 115, 904-911.

Doering-Saad, C., Kämpfer, P., Manulis, S., Kritzman, G., Schneider, J., Zakrzewska-Czerminska, J., Schrempfand, H. \& Barash, I. (1992). Diversity among Streptomyces strains causing potato scab. Appl Environ Microbiol 58, 3932-3940.

Faucher, E., Savard, T. \& Beaulieu, C. (1992). Characterization of actinomycetes isolated from common scab lesions on potato tubers. Can J Plant Pathol 14, 197-202.

Faucher, E., Otrysko, B., Pradis, E., Hodge, N. C., Stall, R. E. \& Beaulieu, C. (1993). Characterization of streptomycetes causing russet scab in Québec. Plant Dis 77, 1217-1220.

Faucher, E., Pradis, E., Goyer, C., Hodge, N., Hogue, R., Stall, R. E. \& Beaulieu, C. (1995). Characterization of streptomycetes causing deep-pitted scab of potato in Québec, Canada. Int $J$ Syst Bacteriol 45, 222-225.

Felsenstein, J. (1981). Evolutionary trees from DNA sequences: a maximum likelihood approach. J Mol Evol 17, 368-376.

Felsenstein, J. (1985). Confidence limits on phylogenies: an approach using the bootstrap. Evolution 39, 783-791.

Fox, G. E., Wisotzkey, J. D. \& Jurtshuk, P., Jr (1992). How close is close: 16S rRNA sequence identity may not be sufficient to guarantee species identity. Int J Syst Bacteriol 42, 166-170.

Goyer, C. \& Beaulieu, C. (1997). Host range of streptomycete strains causing common scab. Plant Dis 81, 901-904. 
Goyer, C., Faucher, E. \& Beaulieu, C. (1996). Streptomyces caviscabies sp. nov., from deep-pitted lesions in potatoes in Québec. Int J Syst Bacteriol 46, 635-639.

Grimont, P. A. D., Popoff, M. Y., Grimont, F., Coynault, C. \& Lemelin, M. (1980). Reproducibility and correlation study of three deoxyribonucleic acid hybridization procedures. Curr Microbiol 4, 325-330.

Harrison, M. D. (1962). Potato russet scab, its cause and factors affecting its development. Am Potato J 39, 368-387.

Healy, F. G. \& Lambert, D. H. (1991). Relationships among Streptomyces spp. causing potato scab. Int J Syst Bacteriol 41, 479-482.

Kimura, M. (1980). A simple method for estimating evolutionary rates of base substitutions through comparative studies of nucleotide sequences. J Mol Evol 16, 111-120.

Kluge, A. G. \& Farris, J. S. (1969). Quantitative phyletics and the evolution of anurans. Syst Zool 18, 1-32.

Labruyère, R. E. (1971). Common Scab and its Control in Seed Potato Crops. Wageningen, the Netherlands: Centre for Agricultural Publishing and Documentation.

Lambert, D. H. \& Loria, R. (1989a). Streptomyces scabies sp. nov., nom. rev. Int J Syst Bacteriol 39, 387-392.

Lambert, D. H. \& Loria, R. (1989b). Streptomyces acidiscabies sp. nov. Int J Syst Bacteriol 39, 393-396.

Mandel, M. \& Marmur, J. (1968). Use of ultraviolet absorbancetemperature profile for determining the guanine plus cytosine content of DNA. Methods Enzymol 12B, 195-206.

Marmur, J. \& Doty, P. (1962). Determination of the base composition of deoxyribonucleic acid from its thermal denaturation temperature. J Mol Biol 5, 109-118.

Mullis, K. B. \& Faloona, F. A. (1987). Specific synthesis of DNA in vitro via a polymerase-catalyzed chain reaction. Methods Enzymol 155, 335-350.

Normand, P., Orso, S., Cournoyer, B., Jeannin, P., Chapelon, C., Dawson, J., Evtushenko, L. \& Misra, A. K. (1996). Molecular phylogeny of the genus Frankia and related genera and emendation of family Frankiaceae. Int J Syst Bacteriol 46, 1-9. Oniki, M., Suzui, T., Araki, T., Sonoda, R., Chiba, T. \& Takeda, T.
(1986). Causal agent of russet scab of potato. Bull Natl Inst Agro-Environ Sci 2, 56-59.

Paradis, E., Goyer, C., Hodge, N. C., Hogue, R., Stall, R. E. \& Beaulieu, C. (1994). Fatty acid and protein profiles of Streptomyces scabies strains isolated in eastern Canada. Int $J$ Syst Bacteriol 44, 561-564.

Perrière, G. \& Gouy, M. (1996). WWW-Query: an on-line retrieval system for biological sequence banks. Biochimie 78, 364-369.

Pridham, T. G. \& Gottlieb, D. (1948). The utilization of carbon compounds by some Actinomycetales as an aid for species determination. J Bacteriol 56, 107-114.

Pridham, T. G., Anderson, P., Foley, C., Lindenfelser, L. A., Hessetine, C. W. \& Benedict, R. G. (1956-1957). A selection medium for maintenance and taxonomic study of streptomycetes. Antibiot Annu 1956-57, 947-953.

Saitou, R. R. \& Nei, M. (1987). A neighbor-joining method: a new method for reconstructing phylogenetic trees. Mol Biol Evol 44 406-425.

Scholte, K. \& Labruyère, R. E. (1985). Netted scab: a new name for an old disease in Europe. Potato Res 28, 443-448.

Shirling, E. B. \& Gottlieb, D. (1966). Methods for characterization of Streptomyces species. Int J Syst Bacteriol 16, 313-340.

Stackebrandt, E. \& Goebel, B. M. (1994). Taxonomic note: a place for DNA-DNA reassociation and 16S rRNA sequence analysis in the present species definition in bacteriology. Int $J$ Syst Bacteriol 44, 846-849.

Takeuchi, T., Sawada, H., Tanaka, F. \& Madsuda, I. (1996). Phylogenetic analysis of Streptomyces spp. causing potato scab based on 16S rRNA sequences. Int J Syst Bacteriol 46, 476-479.

Thompson, J. D., Gibson, T. J., Plewniak, F., Jeanmougin, F. \& Higgins, D. G. (1997). The CLUSTAL-X windows interface: flexible strategies for multiple sequence alignment aided by quality analysis tools. Nucleic Acids Res 25, 4876-4882.

Wayne, L. G., Brenner, D. J., Colwell, R. R. \& 9 other authors (1987). International Committee on Systematic Bacteriology. Report of the ad hoc committee on reconciliation of approaches to bacterial systematics. Int J Syst Bacteriol 37, 463-464. 